\title{
Customers' Perception and the Role of Demographic Characteristics in Online Bank Marketing Strategies
}

\author{
T.S. Uma Rani, Easwaramoorthy Rangaswamy, N. Panchanatham
}

\begin{abstract}
Purpose - the essential purpose of this study is to research the customers' perception and therefore the role of demographic characteristics in on-line bank promoting methods. It helps the bankers as a parameter to boost the character and closeness of relationship between bank promoting methods and therefore the demographic factors particularly, bank customers' standing within the family, gender, age, academic qualification, occupation and monthly financial gain. And to predict the character and closeness of relationship between current perception concerning bank promoting methods and their current position concerning paying of housing loan, important stage of documentation, most frequented bank, variety of account with the bank, variety of coping with the bank, the other checking account, bank with most no. of ATM dealingss and frequent usage of on-line banking transaction.

Design/methodology/approach - Descriptive study was conducted to search out out the extent of relationship that prevails between demographic characteristics and bank promoting methods. 493 questionnaires were collected supported convenient sampling. This study includes each the first and secondary knowledge. Primary knowledge was through the planned form with direct, open-ended and closed-ended multiple alternative queries containing demographic variables and bank promoting methods. The man of science has framed the form supported varied reviews, personal interview with bank managers. Secondary knowledge of the study were gathered from magazines, journal books, through on-line, banking sources, past researches and reviews

Findings - Through multiple correlation analysis, the study reveals that there exist a big relationship between the demographic variables, namely, bank customers standing within the family, gender, age, academic qualification, occupation, monthly financial gain, legal status, religion, current residence, standing of current residence, stick with the family associate degreed bank customers possessing an own house and their perception towards bank promoting methods. and therefore the results showed that there's a big relationship between client perception towards the bank promoting methods and most often used bank, variety of account within the bank, variety of coping with the bank, most most popular ATM, and frequency of visit to the location. This study is additionally valuable to different investigators for coming study.
\end{abstract}

Key words: Bank marketing strategies, customers' perception, Demographic Characteristics, customer satisfaction

\section{INTRODUCTION}

Banking is degree trade that has undergone a forceful change in its commercialism ways thanks to the Ecommerce revolution. web banking refers to the use of the

Revised Manuscript Received on August 05, 2019.

Dr. T.S. Uma Rani, Senior Lecturer, Amity Global Institute, Singapore

Dr. Easwaramoorthy Rangaswamy, Principal \& Provost, Amity Global Institute, Singapore

Dr. N. Panchanatham, Professor \& Head, Department of Business Administration, Annamalai University, Chidambaram. India net as a delivery channel for banking services. Services embrace ancient ones, like gap a certificate of deposit account or transferring funds among utterly completely different account, and new banking services, like electronic bill presentation and payment (allowing customers to receive and pay bills on a banks web site). Banks provide web banking in a pair of main ways that during which. degree existing bank with physical offices established net\} computing device and provide internet banking to its shopper as associate addition to its ancient delivery channels. A second completely different is "virtual," "branchless "or" internet-only" bank. the laptop server that lies at the center of a virtual bank is additionally housed in degree geographic point that's the legal address of such a bank 'or at another location. Virtual banks might provide their shopper the ability to create deposit and withdraw funds via ATMs or completely different remote delivery channel closely-held by alternative institution. the net has giant potential for conducting electronic commerce borderless. As corporations explore electronic commerce, the result's a dramatic change in business commercialism ways and practices. Nelson P, capital of Virginia W (2007)

Doing business through the electronic medium changes the perceptions of the parents involved. This new software package changes the commercialism roles. the net has the potential to point out vertical markets and business functions into horizontal markets that open business processes to new participants in new roles. Banks ought to request on the so much aspect home customers for web Banking. very little businesses are following target for the services. These new services embrace interactive cash management, electronic payments, and investment recommendation, that will generate very important revenues for banks. Like very little businesses, mid-to large sized businesses are a fresh provide of gain for web Banks. Bank's commercialism ways have to be compelled to cowl these recently formed market places as a results of web banking provides not alone a fresh sale channel but to boot intercalary services.

\section{REVIEW OF LITERATURE}

According to Denis Yannacopoulos et.al; (2014), there's a positive impact of gender, age, education, and gain on quality, satisfaction, and value. the results highlights the service quality as a major predictor of perceived price, that in turn is totally related to consumer satisfaction. The mediating/moderating role of perceived price on the 
association between service quality and satisfaction is confirmed. In contrary to the projected hypothesis, no relationships and no variations at intervals the many subgroups categories senior, education, and gain are detected in terms of service quality, value, and satisfaction. Consequently, customers' demographic characteristics limitation on the adoption of on-line banking is presently history. However, the authors counsel that managers invariably take into consideration each section of the customers' demographic profiles one by one whereas making their selections. Vinh add Chau, et al., (2010) investigated the perceptions, attitudes and behavior of the youth marketplace for web banking services (IBS). A survey was disbursed to accumulate info from 164 respondents, World Health Organization were competent laptop users ad sorting out for a degree at a university. three further in-depth interviews were afterward disbursed on attention-grabbing cases. The authors notice that adolescents age (16-29) have further positive attitudes and activity intentions towards using IBS than totally different user-groups. it's to boot confirmed that there's a positive impact of IBS quality on satisfaction and loyalty. The study targeted on associate isolated convenient sample of university students at intervals the GB. The findings won't thus have worldwide significance despite that associate outsized proportion of the students were international and from a good illustration of minority ethic groups. The analysis targeted on a particular section of the online banking services market, younger student at a GB university. The findings are useful for bank services merchandising as a result of the young are likely to become the foremost necessary section of users because the worldwide web and banking services become further advanced at intervals the longer term. Uma Rani T.S. and Panchanatham, N. (2011) in their article they created a shot to go looking out out the association that exist among the merchandising strategies adopted by the banks and so the amount of consumer perception towards it. The descriptive analysis vogue has been used. Convenient sampling is utilized to assemble the data from 2 hundred samples from Trichy city. throughout this study, merchandising Strategy is treated as a result of the freelance or variable and so the factors touching these strategies are treated because the dependent or Criterion variable. thus on scrutinize the association between variables, Correlation is calculated. The results showed that there's a positive relationship between the purposeful Strategy factors (Bank Charges and Interest Rates, staff Competencies and dependability,) and CRM factors (Customization and communication) severally. The results established that there exists really durable correlation among overall merchandising strategies and dependability ( $\mathrm{r}$ \&gt; zero.80). and so the explanations for selecting the foremost frequented bank was called location convenience, bank customization, Infrastructure facilities, bank image, on-line banking and friendly staff and for larger speed for ATM Kirti Dutta and Anil Dutta (2009) targeted on the consumer expectation and perceptions across the Indian industry and so the resultant cash implications. the aim of this paper painted the factors touching the quality perception of the purchasers at intervals the banking sector and has tried to corroborate this perception with the money performance of the banks. The paper presents the primary info of 263 respondents across the three banking sectors. A study of the money performance of the banks was to boot done to examine if the perception of service quality options a consequence on the banks bottom line. it had been found that at intervals the banking sector, the foreign banks were gave the impression to supply higher quality of services followed by the private thus public banks. it had been to boot found that these perceptions were reflected at intervals the money performance of the banks additionally. With the increasing competition amongst banks, the findings can act as a strategic tool to achieve competitive advantage and consumer satisfaction. it's to boot a watch opener for the banks to examine the gap between consumer expectation and perception regarding the quality of services rendered that need to any act as a motive to spice up name and gain client loyalty. this might in turn offer them the elusive competitive edge they're finding out. Ganesan-Lim et al., (2008) argued that it's of predominate importance to understand the association between the customer's perception of service quality and demographic information like age, gender, education and gain level. Obviously, this information $\{$ is alsolis to boot $\}$ useful for safeguarding that there are acceptable product and services a vailable for the target market. according to Ganesan-Lim et al., (2008) study at intervals the traditional services, ladies were further in favor of looking out activities as a results of they were generally guilty of the organization searching and hold a lot of positive attitudes towards the quality store to boot to catalogue shopping than their male counterparts. Moreover, supported constant level of the common satisfaction. Mittal and Kamakura (2001) argued that subjects with education tend to possess lower levels of retention than those with a lycee education or less. The authors any agued that the chance of repurchase among ladies was uniformly on top of among men that older customers repurchase probability is higher. additionally, they're going to have stable preferences than younger customers.

\section{METHODOLOGY OF THE STUDY}

The necessity of this study to find the Customers' Perception and the Role of Demographic Characteristics in bank marketing strategies. The study was conducted among the customers of commercial banks in India. Descriptive study was conducted to find out the level of relationship that prevails between demographic characteristics and bank marketing strategies. 493 questionnaires were collected based on convenient sampling. This study includes both the primary and secondary data. Primary data was through the planned questionnaire with direct, open-ended and closedended multiple choice questions containing demographic variables and bank marketing strategies. The researcher has framed the questionnaire based on various reviews, personal interview with bank managers. Secondary data of the study were gathered from magazines, journal books, through online, banking sources, past researches and reviews.

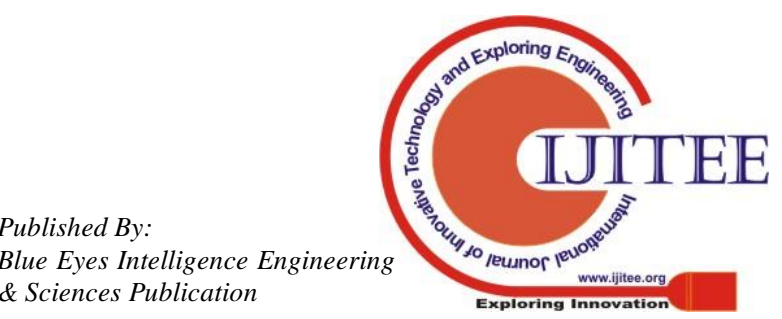




\section{OBJECTIVES OF THE STUDY}

1. to research the role of demographic variables that influences the customers' perception on selling methods of banks.

2. to seek out the connection between demographic variables and customers' perception towards bank selling methods. the bank customers and their perception towards bank selling methods

Banking is degree trade that has undergone a forceful modification in its mercantilism methods due to the Ecommerce revolution. web banking refers to the employment of world wide web as a delivery channel for banking services. Services embrace ancient ones, like gap a certificate of time deposit account or transferring funds among totally fully completely different account, and new banking services, like electronic bill presentation and payment (allowing customers to receive and pay bills on a banks internet site). Banks offer internet banking during a try of main ways in \{which\} at intervals which. degree existing bank with physical offices established a web computing machine and supply web banking to its shopper as associate addition to its ancient delivery channels. A second fully completely different is "virtual," "branchless "or" internet-only" bank. the laptop computer server that lies at the guts of a virtual bank in addition \} housed in degree work that's the legal address of such a bank 'or at another flexibility to create deposit and withdraw funds via ATMs or fully completely different remote delivery channel in hand by different establishment. world wide web has large potential for conducting electronic commerce borderless. As companies explore electronic commerce, the result's a dramatic modification in business mercantilism methods and practices. Nelson P, Richmond W (2007)

Doing business through the electronic medium changes the perceptions of the fogeys concerned. This new code package changes the mercantilism roles. world wide web has the potential to show vertical markets and business functions into horizontal markets that open business processes to new participants in new roles. Banks have to be compelled to request on the such a lot facet home customers for internet Banking. little or no businesses are following target for the services. These new services embrace interactive money management, electronic payments, and investment recommendation, which is able to generate necessary revenues for banks. Like little or no businesses, mid-to massive sized businesses are a clean offer of gain for internet Banks. Bank's mercantilism methods got to cowl these recently fashioned market places as a results of internet banking provides not completely a clean sale channel however additionally further services.

\section{REVIEW OF LITERATURE}

According to Denis Yannacopoulos et.al; (2014), there's a positive impact of gender, age, education, and gain on quality, satisfaction, and value. the results highlights the service quality as an enormous predictor of perceived worth, that in turn is totally related to shopper satisfaction. The
3. to seek out the connection between current position of location. Virtual banks may offer their shopper the

mediating/moderating role of perceived worth on the association between service quality and satisfaction is confirmed. In contrary to the projected hypothesis, no relationships and no variations at intervals the numerous subgroups categories senior, education, and gain are detected in terms of service quality, value, and satisfaction. Consequently, customers' demographic characteristics limitation on the adoption of on-line banking is presently history. However, the authors advocate that managers invariably take into thought each a locality of the customers' demographic profiles one by one whereas making their picks. Vinh add Chau, et al., (2010) investigated the perceptions, attitudes and behavior of the youth marketplace for internet banking services (IBS). A survey was applied to accumulate data from 164 respondents, World Health Organization were competent notebook computer users ad checking out for a degree at a university. three a lot of indepth interviews were shortly applied on attention-grabbing cases. The authors notice that adolescents age (16-29) have more positive attitudes and activity intentions towards exploitation IBS than totally whole totally different usergroups. it's to boot confirmed that there's a positive impact of IBS quality on satisfaction and loyalty. The study targeted on degree isolated convenient sample of university students at intervals the united kingdom of nice uk of nice Great Britain and European country and European country. The findings won't so have worldwide significance despite that associate outsized proportion of the students were international Associate in Nursingd from an honest illustration of minority ethic groups. The analysis targeted on a selected a locality of net banking services market, younger student at a \{uk|United Kingdom|UK|Great Britain|GB|Britain|United Kingdom of nice Britain and Northern Ireland|kingdom $\}$ of nice uk of Great Britain and European country and European country university. The findings are useful for bank services dealing as a results of the young are all told likelihood to become the foremost necessary a locality of users as a results of the worldwide internet and banking services become more advanced at intervals the long run. Uma Rani T.S. and Panchanatham, N. (2011) in their article they created a trial to travel looking the association that exist among the dealing ways adopted by the banks and thus the amount of client perception towards it. The descriptive analysis vogue has been used. Convenient sampling is utilized to assemble the data from a combine of hundred samples from Trichy city. throughout this study, dealing Strategy is treated as a results of the freelance or variable and thus the factors touching these ways are treated as a results of the dependent or Criterion variable. so on examine the association between variables, Correlation is calculated. The results showed that there's a positive relationship between the purposeful Strategy factors (Bank Charges and Interest Rates, employees Competencies and responsibleness,) and CRM factors (Customization and communication) severally. The results established that there exists extraordinarily durable correlation among overall dealing ways and responsibleness (r \&gt; zero.80). and thus 
the explanations for selecting the foremost frequented bank was stated as location convenience, bank customization, Infrastructure facilities, bank image, on-line banking and friendly employees and for larger speed for ATM Kirti Dutta and Anil Dutta (2009) targeted on the patron expectation and perceptions across the Indian banking industry and thus the resultant cash implications. the aim of this paper painted the factors touching the quality perception of the purchasers at intervals the banking sector and has tried to corroborate this perception with the cash performance of the banks. The paper presents the primary data of 263 respondents across the three banking sectors. A study of the cash performance of the banks was to boot done to seem at if the perception of service quality decisions a consequence on the banks bottom line. it had been found that at intervals the banking sector, the foreign banks were gave the impression to supply higher quality of services followed by the private so public banks. it had been to boot found that these perceptions were reflected at intervals the cash performance of the banks together. With the increasing competition amongst banks, the findings can act as a strategic tool to realize competitive advantage and shopper satisfaction. it's to boot a watch opener for the banks to seem at the gap between shopper expectation and perception with connexion the quality of services rendered that need to any act as a motive to spice up name and gain shopper loyalty. this could in turn offer them the elusive competitive edge they're checking out. Ganesan-Lim et al., (2008) argued that it's of predominate importance to grasp the association between the customer's perception of service quality and demographic data like age, gender, education and gain level. Obviously, this data is additionally useful for safeguarding that there are applicable product and services a vailable for the target market. in step with Ganesan-Lim et al., (2008) study at intervals the conventional services, ladies were more in favor of wanting activities as a results of they were sometimes guilty of the unit wanting and hold lots of positive attitudes towards the quality store to boot to catalogue looking than their male counterparts. Moreover, supported constant level of the common satisfaction. Mittal and Kamakura (2001) argued that subjects with education tend to have lower levels of retention than those with a secondary school school education or less. The authors any agued that the prospect of repurchase among ladies was uniformly over among men that older customers repurchase probability is higher. additionally, they're getting to have stable preferences than younger customers.

\section{RESULTS AND DISCUSSIONS}

Table 1: Relationship between demographic variables and customers' perception towards bank marketing strategies

To predict the nature and closeness of relationship between bank marketing strategies and the demographic factors namely, bank customers' status in the family, gender, age, educational qualification, occupation and monthly income, simple regression analysis was applied.

\begin{tabular}{|c|c|c|c|c|c|c|c|c|}
\hline No & $\begin{array}{l}\text { Demographic } \\
\text { variables }\end{array}$ & $\begin{array}{l}R \\
\text { value }\end{array}$ & $\begin{array}{l}R \text { square } \\
\text { value }\end{array}$ & F value & $\begin{array}{l}\text { Consta } \\
\text { nt }\end{array}$ & $\begin{array}{c}\text { Beta } \\
\text { value }\end{array}$ & $\mathrm{t}$-value & Significance \\
\hline 1 & $\begin{array}{l}\text { Bank customers' } \\
\text { Status in the Family } \\
\left(\mathrm{X}_{1}\right)\end{array}$ & 0.133 & 0.018 & 8.809 & 2.392 & -0.158 & -2.968 & $0.003^{* *}$ \\
\hline 2 & Gender $\left(\mathrm{X}_{2}\right)$ & 0.043 & 0.002 & 0.912 & 1.348 & -0.124 & -0.955 & $0.034 *$ \\
\hline 3 & Age $\left(\mathrm{X}_{3}\right)$ & 0.124 & 0.015 & 7.728 & 1.806 & 0.186 & 2.780 & $0.006^{* *}$ \\
\hline 4 & $\begin{array}{ll}\text { Educational } & \text { Level } \\
\left(\mathrm{X}_{4}\right) & \end{array}$ & 0.065 & 0.004 & 2.058 & 4.011 & 0.191 & 1.435 & $0.012 *$ \\
\hline 5 & Occupation $\left(\mathrm{X}_{5}\right)$ & 0.099 & 0.010 & 4.882 & 2.341 & -0.141 & -2.210 & $0.028^{*}$ \\
\hline 6 & Monthly Income $\left(\mathrm{X}_{6}\right)$ & 0.249 & 0.062 & 25.232 & 0.958 & 0.339 & 5.023 & $0.000^{* *}$ \\
\hline 7 & $\begin{array}{l}\text { Marital status } \\
\left(\mathrm{X}_{7}\right)\end{array}$ & 0.204 & 0.042 & 21.360 & 1.727 & -0.125 & -4.622 & $0.000^{* *}$ \\
\hline 8 & $\begin{array}{l}\text { Religion } \\
\left(\mathrm{X}_{8}\right)\end{array}$ & 0.067 & 0.005 & 2.244 & 1.143 & 0.043 & 1.498 & 0.135 \\
\hline 9 & $\begin{array}{ll}\text { Current } & \text { Residence } \\
\left(\mathrm{X}_{9}\right) & \end{array}$ & 0.115 & 0.013 & 6.604 & 1.997 & -0.120 & -2.570 & $0.011^{*}$ \\
\hline 10 & $\begin{array}{l}\text { Status of current } \\
\text { Residence }\left(\mathrm{X}_{10}\right)\end{array}$ & 0.013 & 0.000 & 0.083 & 2.230 & -0.015 & -1.288 & $0.043^{*}$ \\
\hline 11 & $\begin{array}{l}\text { Stay with the Family } \\
\left(\mathrm{X}_{11}\right)\end{array}$ & 0.047 & 0.002 & 1.094 & 1.102 & 0.020 & 1.046 & 0.296 \\
\hline 12 & $\begin{array}{l}\text { Possessing a } \text { Own } \\
\text { House }\left(\mathrm{X}_{12}\right)\end{array}$ & 0.020 & 0.000 & 0.202 & 1.375 & 0.012 & 0.450 & 0.653 \\
\hline
\end{tabular}

Note: * Significant at the 0.05 level (2-tailed) $* *$ Significant at the 0.01 level (2-tailed)

S- Significant NS- Not Significant 
Regression take a look at is completed to discover the relation among demographic variables and customers' perception towards financial organization advertising and advertising techniques.

The end result determined that there may be a massive dating amongst customer belief towards the monetary organization marketing and marketing strategies and the demographic variables specifically, monetary corporation patron's recognition in the circle of relatives, gender, age, instructional degree, career, month-to-month income, marital recognition, present day residence, and status of modern-day house. the opportunity demographic variables of the financial institution customers like faith, stay with the own family and owning an personal residence does not have an impact at the purchaser perception in the direction of economic group advertising and advertising and marketing strategies.

$\mathrm{R}$ charge shows the connection the numerous demographic variables, mainly, monetary organization clients popularity inside the own family, gender, age, instructional qualification, profession, monthly profits, marital popularity, faith, contemporary residence, fame of current-day house, stay with the own family and monetary organization clients owning a personal residence and their notion in the direction of monetary group marketing strategies. R square fee indicates the variant in patron belief closer to not unusual financial institution advertising techniques for the elements specifically, monetary employer clients reputation within the own family $(1.8 \%)$, gender ( $0.2 \%)$, age $(1.5 \%)$, instructional qualification $(0.4 \%)$, profession $(1 \%)$, monthly profits $(6.2 \%)$, marital reputation $(4.2 \%)$, religion (zero.five $\%)$, modern-day residence $(1.3 \%)$, live with the own family $(0.2 \%)$.

Regression equation $\mathrm{Y}=$ everyday fee $+\mathrm{X}$ (Beta price)

$\mathrm{Y}$ is the based totally totally variable; right here client perception inside the route of monetary organization advertising strategies is the established variable

$\mathrm{X}$ is the impartial variable. The demographic variables are unbiased variables.

Bank customers' status in the family, $\mathrm{Y}=2.392+(-)$ $0.158 \mathrm{X}^{1}$

Gender, $\mathrm{Y}=1.348+(-) 0.124 \mathrm{X}^{2}$

Age, $\mathrm{Y}=1.806+0.186 \mathrm{X}^{3}$

Educational qualification $\mathrm{Y}=4.011+0.191 \mathrm{X}^{4}$

Occupation $\mathrm{Y}=2.341+(-) 0.141 \mathrm{X}^{5}$

Monthly Income $\mathrm{Y}=0.958+0.339 \mathrm{X}^{6}$

Marital status $\mathrm{Y}=1.727+(-) 0.125 \mathrm{X}^{7}$

Religion $\mathrm{Y}=1.143+0.043 \mathrm{X}^{8}$

Current Residence $\mathrm{Y}=1.997+(-) 0.120 \mathrm{X}^{9}$

Status of current residence $Y=2.230+(-) 0.015 \mathrm{X}^{10}$

Stay with the family $Y=1.102+0.020 \mathrm{X}^{11}$

Possessing a own house $\mathrm{Y}=1.375+0.012 \mathrm{X}^{12}$

The on top of equation describes that the demographic variables will increase by zero.339 unit for each one unit increase in monthly financial gain, 0.191 unit for each one unit increase within the education level, 0.186 unit for each one unit increase in age, et al. doesn't increase. supported this monthly financial gain, education level and age are the most effective variables out of twelve demographic variables.
If the ' $p$ ' price is a smaller amount than zero. 01 or 0.05 , then the numerous relationship exists between the experimental variable and dependent variable. a big relationship exists between freelance variables specifically, bank customers standing within the family $(\mathrm{X} 1=-0.158, \mathrm{p}$

Table 2: Relationship between current position of the

bank customers and their perception towards bank marketing strategies

To predict the character and closeness of relationship between current perception concerning bank selling ways and their current position relating to paying of housing loan, important stage of documentation, most frequented bank, style of account with the bank, style of addressing the bank, the other checking account, bank with most no. of ATM dealingss and frequency of on-line banking transaction, regression analysis was done. 


\begin{tabular}{|l|l|l|l|l|l|l|l|l|}
\hline $\mathbf{N o}$ & $\begin{array}{l}\text { Current Position of the } \\
\text { bank customers }\end{array}$ & $\begin{array}{l}\mathbf{R} \\
\text { value }\end{array}$ & $\begin{array}{l}\mathbf{R} \\
\text { square } \\
\text { value }\end{array}$ & $\mathbf{F}$ value & $\begin{array}{l}\text { Cons } \\
\text { tant }\end{array}$ & $\begin{array}{l}\text { Beta } \\
\text { value }\end{array}$ & t- value & $\begin{array}{l}\text { Signfica } \\
\text { nce }\end{array}$ \\
\hline 1 & $\begin{array}{l}\text { Paying of Housing Loan } \\
\left(\mathrm{X}_{1}\right)\end{array}$ & 0.095 & 0.009 & 4.431 & 2.383 & -0.188 & -2.105 & 0.136 \\
\hline 2 & $\begin{array}{l}\text { Critical Stage of } \\
\text { Documentation (X) }\end{array}$ & 0.057 & 0.003 & 0.273 & 2.318 & -0.084 & -0.522 & 0.603 \\
\hline 3 & \begin{tabular}{l} 
Most Frequented bank $\left(\mathrm{X}_{3}\right)$ \\
\hline 4
\end{tabular} & 0.452 & 0.205 & 126.371 & 1.480 & 0.110 & 11.241 & $0.000^{* *}$ \\
\hline 5 & $\begin{array}{l}\text { Type of account with the } \\
\text { Bank }\left(\mathrm{X}_{4}\right)\end{array}$ & 0.127 & 0.016 & 7.989 & 1.878 & 0.120 & 2.827 & $0.005^{* *}$ \\
\hline 6 & $\begin{array}{l}\text { fype of dealing with most } \\
\text { Any Other Bank account } \\
\left(\mathrm{X}_{6}\right)\end{array}$ & 0.038 & 0.001 & 0.713 & 2.131 & -0.048 & -0.845 & 0.399 \\
\hline 7 & \begin{tabular}{l} 
Most preferred ATM $\left(\mathrm{X}_{7}\right)$ \\
\hline 8
\end{tabular} & 0.325 & 0.106 & 57.943 & 1.653 & 0.080 & 7.612 & $0.000^{* *}$ \\
\hline
\end{tabular}

Note: * Significant at the 0.05 level (2-tailed) ** Significant at the 0.01 level (2-tailed)

S- Significant NS- Not Significant

The results show that there's a big relationship between client perception towards the bank promoting ways and most often used bank, kind of account within the bank, kind of managing the bank, most most popular ATM, and frequent usage of on-line banking group action. the opposite factors, paying housing loan, crucial stage of documentation and the other checking account doesn't influence the client perception towards bank promoting ways. $\mathrm{R}$ price indicates the link between paying of housing loan, crucial stage of documentation, most often used bank, kind of account within the bank, kind of managing the bank, the other checking account, bank with most no. of ATM group action and frequency of on-line banking transaction with client perception towards bank promoting ways. $\mathrm{R}$ sq. price indicates that proportion of variation with client perception towards the general bank promoting ways.

Regression equation $\mathrm{Y}=$ Constant price $+\mathrm{X}$ (Beta value)

$\mathrm{Y}$ is that the variable quantity; here client perception towards bank promoting ways is the dependent variable

$\mathrm{X}$ is that the variable. Here the present positions of the bank customers are freelance variables.

Paying of housing loan, $\mathrm{Y}=2.383+(-)$ zero. $188 \mathrm{X} 1$

Critical stage of documentation, $\mathrm{Y}=2.318+(-)$ zero.084X2

Most frequented bank, $\mathrm{Y}=1.480+0.110 \mathrm{X} 3$

Type of account with the bank $\mathrm{Y}=$ one.878+0.120 X4

Type of managing the foremost frequented bank $\mathrm{Y}=$ two.407+ (-) 0.083 X5

Any other checking account $\mathrm{Y}=$ two.131 $+(-)$ zero.048X6

Most most popular ATM Y $=$ one $.653+0.080 \mathrm{X} 7$
Frequency of on-line banking group action $\mathrm{Y}=$ two. $183+$ $0.044 \mathrm{X} 8$

The on top of equations describes that the present position of the bank customers will increase by zero.120 unit for each one unit increase in kind of account with the bank, 0.110 unit for each one unit increase within the most often used bank by the bank customer's, 0.080 unit for each one unit increase in most most popular ATM and zero.044 unit for each one unit increase in frequency of on-line banking group action supported this, kind of account the bank customer's posses with the bank, most often used bank by the bank customer's, most most popular ATM and frequency of on-line banking group action by them are the simplest variables out of eight variables.

If the 'p' price is a smaller amount than zero.01 or 0.05 , then the numerous relationship exists between the variable and dependent variable. a big relationship exists between freelance variables particularly, the foremost frequented bank (X3 = zero.110), kind of account within the bank (X4 $=$ zero.120), kind of managing the bank $(\mathrm{X} 5=-0.083)$, most most popular ATM $(\mathrm{X} 7=$ zero.080), frequency of on-line banking group action (X8 = zero.044) and client perception towards the bank ways. And so the regression depends on however and to what extent the present position of the bank clients influence the customer perception towards the bank promoting.

The study created by Sudha Dhawan (2009) supports the researcher's opinion and known that accessibility of ATMs 
finds a high priority in client bank choice. thence banks have to be compelled to provide due importance in establishing a large ATM network or going in alliances with varied banks. whereas learning the shift behavior or bank shoppers, accessibility of technology-based services and kind of managing the banks are found to be the main reasons for shoppers to change banks. thence banks have to be compelled to work on these areas to know the requirements of the consumer and have to implement ways to satisfy the needs so as to existing shoppers and attract new clients.

\section{FINDINGS \&AMP; CONCLUTION}

Since banking is in its core a trade, most transactions are dependent on the sort of relationships that the banks share with people who trust in them. In different words, relationship promoting is termed as a result of the pillars of bank stability. the knowledge gathered and its analysis helps in having a clear image of the consumer profile understanding world organisation agency wants What, once and therefore the means much? And meeting expectations of the consumer as closely as achievable. the conception of consumer satisfaction is to provide the client. What the consumer wants? once the client wants?, where the consumer wants? and therefore the means the client wants? therefore on survive inside the gift day world of competition, the banks will need to be compelled to formulate on-line promoting ways in which in an exceedingly\} very because of persuade the patrons towards them. Level of consumer satisfaction is popping into one altogether the most targets inside the hand of banks to increase their market share. To predict the character and closeness of relationship between bank promoting ways in which and thus the demographic factors significantly, bank customers' standing inside the family, gender, age, tutorial qualification, occupation and monthly gain, method analysis was applied. and placed that there exists the various relationship between the demographic variables, namely, bank customers standing inside the family, gender, age, tutorial qualification, occupation, monthly gain, status, religion, current residence, standing of current residence, follow the family and bank customers possessing a own house and their perception towards bank promoting ways in which. To predict the character and closeness of relationship between current perception relating to bank promoting ways in which and their current position regarding paying of housing loan, crucial stage of documentation, most frequented bank, quite account with the bank, quite managing the bank, the opposite bank account, bank with most no. of ATM transactions and frequency of visit, method analysis was done. and thus the results showed that there's a giant relationship between consumer perception towards the bank promoting ways in which and most frequently used bank, quite account inside the bank, quite managing the bank, most preferred ATM, and frequency of visit. the other factors, paying housing loan, crucial stage of documentation and therefore the alternative bank account doesn't influence the consumer perception towards bank promoting ways in which

\section{REFERENCES}

1. Aaker, David. A. (2008). Strategic Market Management New York :John Wiley

2. Beckett, A., Hewer. O., \& Howcroft, B. (2000). An exposition of consumer behavoiur in the financial service industry. The International Journal of Bank Marketing, 18(1), 15.

3. Denis Yannacopoulos, Panagiotis Manolitzas, Nikolaos Matsatsinis and Evangelos Grigoroudis (2014), "Customer Satisfaction and the Role of Demographic Characteristics in Online Banking", Evaluating Websites and Web Services: Interdisciplinary Perspectives on User Satisfaction, Publisher: IGI Global, pp.138-154.

4. Engel, J.F., Blackwell, R.D., and Miniard, P.W. (1995): Consumer Behaviour. Hinsdale, IL: Dryden Press.

5. Ganesan-Lim, C., Russell-Bennett, R., \& Dagger, T. (2008). The impact of service contact type and demographic characteristics on service quality perceptions. Journal of Services Marketing, 22(7). doi:10.1108/0887604081090967

6. Kirti Dutta., Anil Dutta. (2009). Customer expectation and perceptions across the Indian Banking industry and the resultant financial implications. Journal of Services Research. 9(1), 31-49.

7. Mayer., and Buckley. (1970). An Examination of the Pathways through Which Social Class Impacts Health Outcomes. Academy of Marketing Science Review.

8. Mittal, V \& Kamakura, W. A. (2001). Satisfaction, repurchase intent and repurchase behaviour: Investigating the moderating effect of customer characteristics. JMR, Journal of Marketing Research, 38(1), 131-142. doi:10.1509/jmkr.38.1.131.1883

9. Nelson P, Richmond W (2007). Internet Banking: Gold Mine or Money Pit? Academy of Banking Studies Journal 6: 1-25.

10. Perrier., Pierse Filiatrault., and Line Richard. (1992). Relationship Marketing and Commercial Banking: A Critical Analysis. The International Journal of Bank Marketing, 10(7), 5.

11. Reidenbach, R.E. (1995). Value-Driven Bank: Strategies for Total Market Satisfaction. Irwin Professional, U.K.

12. Sudha Dhawan. (2009). An insight into factors influencing bank selection decisions of Indian customers Institute of Productivity \& management, 13, pp. 21-31.

13. Suganthi., Balachander., and balachandran. (2001). Internet Banking Patronage: An Empirical Investigation of Malaysia. Journal of Internet Banking and Commerce, $6(1)$

14. Uma Rani, T.S., Dr. Panchanatham, N. (2011). Impact of Marketing Strategies in Enhancing the customer perception towards Banks. International Journal of Retailing and Marketing, 173-179.

15. Vinh Sum Chau, liqing W.L.C., Nagai. (2010). The youth market for internet banking services perceptions, attitude and behaviour. Journals of services marketing, 24(1). 